\title{
Human Capital Orientation, Employee Creativity Development, Organizational Innovation Capabilities, and Outstanding Performance of SMEs Businesses in Thailand
}

Submitted 13/03/21, 1st revision 10/04/21, 2nd revision 02/05/21, accepted 25/05/21

\section{Dararat Thatrak ${ }^{1}$}

\begin{abstract}
:
Purpose: This research aims to study the effects of human capital orientation on employee creativity development, organizational innovation capabilities, and SME businesses' outstanding performance in Thailand.

Design/Methodology/Approach: 400 SMEs businesses are the sample of this study from August to October 2020 by a mail survey procedure via the questionnaire; the database is derived from the Small and Medium Enterprise Promotion Office website in Thailand. Two hundred nineteen responses were received and usable. The structural equation model (SEM) investigated the effects of human capital orientation, employee creativity development, organizational innovation capabilities, and outstanding performance are investigated by structural equation model (SEM).

Findings: The research results were found that the independent variable is human capital orientation has a direct positive influence on employee creativity development. Employee creativity development has a direct positive influence on organizational innovation capabilities, and organizational innovation capabilities have a direct positive influence on outstanding performance.

Practical Implications: The results of this study point out that supporting the development of human capital orientation is an essential factor affecting creativity, organizational innovation capabilities, and outstanding firm performance which SMEs companies that are accelerating recovery, executives can apply information to benefit in the human capital development in the company. The company encourages employees to think joint initiative and create something new that is ready to cope with the organization's changes to relate with innovation and new information technology to lead the organization to survive and gain a competitive advantage.

Originality/Value: This research integrates three concepts of the resource base theory, contingency theory, and dynamic capabilities that SMEs businesses use their resources to create values and competence in current situations facing threats from the external environment that severely impact their operations.
\end{abstract}

Keywords: Human capital orientation, employee creativity development, organizational innovation capabilities, outstanding performance.

JEL classification: MO.

Paper Type: Research Paper.

${ }^{1}$ Faculty of Business Administration and Liberal Art, Rajamangala University of Technology Lanna Lampang, Lampang Province, Thailand, dararat_6@rmutl.ac.th 


\section{Introduction}

From the current situation, businesses face rapid change. In particular, the coronavirus outbreak (COVID 19) situation. The organization must change quickly due to responding to the travel ban, detention, employee restructuring, layoffs, including spacing (McCulloch, 2020; Thomas, Campbell, and Hancock, 2020). It is a big challenge that affects the overview of the World economy and Thailand severely, causing the economy to fluctuate, halt, and damage all businesses that need to accelerate rehabilitation (Wolor et al., 2020; Wei and Wong, 2020). The same as SMEs in Thailand with economic conditions in total product value in the first quarter of 2020 contracted 303 percent. Most entrepreneurs need to focus on adaptation to support the change, accelerate recovery, adapt to increase the chances of survival and the growth rate of the organization; this is because SMEs are essential to driving the country's economy, and it is also the main employment business of the country. (Abdul-Mohsin, Halim, and Ahmad, 2020; Office of Small and Medium Enterprises Promotion, 2020). From the company's resources and capabilities, focusing on human resources is essential for the company to survive.

Human capital is the most valuable resource of an organization that brings a competitive advantage in value creation, hard to find, and has a high replication cost. Therefore, it is a unique resource (Barney, 1991; Nguyen et al., 2020; Onkelinx, Manalova, and Edelman, 2016; Ployhart, Van Iddeking, and Mackenzie Jr., 2011; Subramanian, 2012). This can be seen from the redefining of the SMEs business that emphasizes the use of the amount of employment and income in the operator's size. (Office of Small and Medium Enterprises Promotion, 2020). It pointed out that the first factor that corporate executives should focus on in the business rehabilitation is human capital in the organization, which the operations of SMEs in each business will have different characteristics. The characteristics of human resources within the organization that respond to problems are not the same.

Therefore, human capital should be given more emphasis (Kelliher and Reinl, 2009). Human capital can enhance the ability to create value for a company from knowledge, skills, abilities, experience, personality, creative expertise embedded in a person. If it has been developed continuously, it can lead to the company's economic value creation because the developed personnel will effectively return their capital to develop the organization (Alsafadi and Altahat, 2021; Thammawimutti and Chuntuk, 2017; Wang et al., 2010). If the organization supported the personnel creativity, allow the organizations to discover new and better operational processes to develop the organization's ability to create innovation (Sijabat, Nimran, Utami, and Prasetya, 2021).

Therefore, if the organization can find a proper management process of human capital will give the company has the highest return, especially in the present situation. Human capital is essential to every transition and facing a crisis. The organization began to adapt from the transition from the resource-based economy to 
the digital economy. Operation on technology and innovation is the critical point to help organizations work more efficiently (Hariyono and Tjahjadi, 2021). Therefore, it is imperative to adjust human capital's thinking and action in line with the occurred changes. It is developing the company's personnel skills and competencies to have the skills and ability to perform tasks to increase operational efficiency that continuously bring the long-term company survival.

This study has objectives to investigate the effects of human capital orientation on employee creativity development, organizational innovation capabilities, and SME businesses' outstanding performance in Thailand. SMEs are a suitable example of this study due to much employment. Human capital development is an integral part of the country's economic operating. Having knowledge, skills, ability, and creativity towards better innovation helps organizations face and survive in intensely competitive environments. For this reason, three research questions are presented: 1) how does human capital orientation lead to employee creativity development, organizational innovation capabilities, and outstanding performance? 2) how does employee creativity develop to have the organizational innovation capability and outstanding performance? Moreover, 3) how does organizational innovation capability produce outstanding performance? The details of this study are outlined below. The relevant first part of the review on human capital orientation literature and develops the critical research hypotheses-next details the research methods used in hypothesis testing. Moreover, the results of the empirical investigation are presented and discussed. Lastly, theoretical, and managerial contribution, study limitations, and conclusions are presented with future research recommendations.

\section{Literature Review, Theoretical Framework, and Hypotheses Development}

A resource-based theory perspective (RBV) described the resources and capabilities available to the company that affects its success and sustainable competitiveness because they are valuable resources and abilities, rare, which are hard to be imitated irreplaceable (Barney, 1991). However, the environment has changed, and all businesses were severely affected by the current coronavirus pandemic. Although the organization has many resources and capabilities, it could not make the organization survive. The organization should develop dynamic organizational capabilities and support employees to develop their knowledge and ability (Wang and Ahmed, 2007). To cope with the rapid change, the organization should pay more attention to adaptation in a highly uncertain environment. Organization management adapts to the emergency theoretical situations to provide flexibility following the changing environment all the time (Robbins and Coulter, 2016). That is the concept of resource base theory, which must be integrated with dynamic capabilities and contingency theory that explain the importance of human capital for employees to develop creative abilities to create innovations that are valuable to the organization and outstanding performance. As shown in Figure 1, the development of the research framework is as follows. 
Figure 1. The framework concepts of the relationships between human capital orientation, employee creativity development, organizational innovation capabilities, and outstanding performance

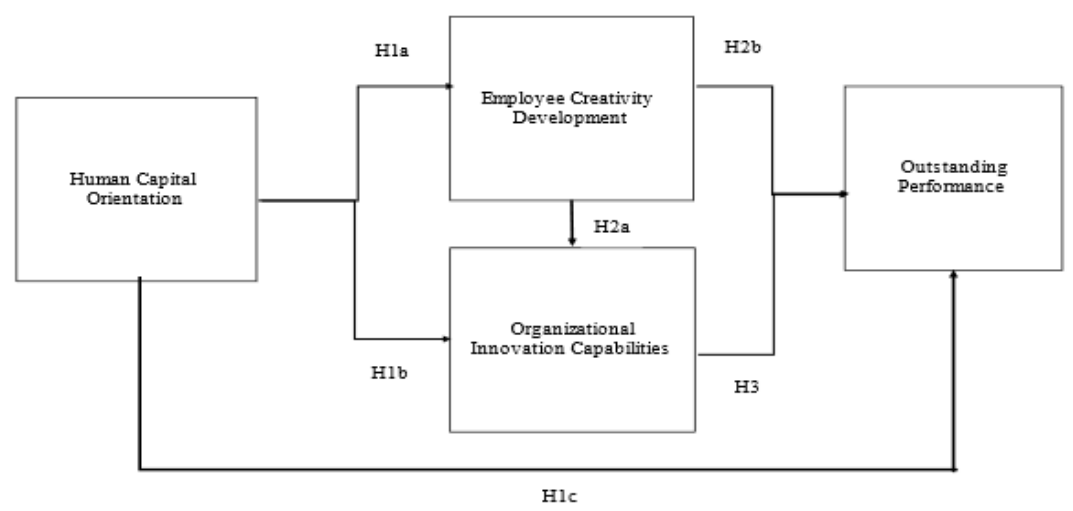

Source: Own creation.

\subsection{Human Capital Orientation}

Human capital orientation emphasizes the use of intellectual capital, skills, abilities, including personal experiences, for enhancing the operational potential to achieve the goal, which is an intangible asset (Baron and Armstrong, 2007). Therefore, human capital can be considered an asset of an embedded person and attach to the person when leaving the organization (Ehrenberg and Smith, 2003). The organization should invest in human capital with personnel to proceed with activities that create value to be an effective organization. It can also lead the organization to operate by combining knowledge, skills, abilities, experience as well as the expertise of each person that accumulates in itself together which can make the organization increase work efficiency and an advantage over the rival the changes that occur (Hatch and Dyer, 2004; Mahsud, Yukl, and Prussia, 2011; Urbano, Alvarez, and Turro, 2013; Jansawang, and Prombutara, 2019; Hareebin, 2020).

Human capital is a capability that exists in many areas of a person who is born or born out of learning. Building more experiences human capital will also increase either knowledge or explicit knowledge. Survived and achieved organizations in changing situation often comes from the competence of qualified personnel which created added value and competitive advantage (Milumaieng, 2016; Pinkesorn, Kittisaknawin, and Kongklai, 2017; Dechawatanapaisal, 2017; Lupong, 2012).

Human capital orientation on this research focuses on increasing the ability to learn, operational efficiency, and bringing out employees' capability to increase the organization's capacity to restore, survive, and thrive in the rapid changes that organizations face. Human capital orientation at the company level that place 
focuses on talent and work skills, leading to the ability to create the company's innovation (Yen, 2014). Bring up the following assumptions:

H1: Human capital orientation positively affects (a) employee creativity development, (b) organizational innovation capabilities, and (c) outstanding performance.

\subsection{Employee Creativity Development}

Employee creativity development means aiming to create new and different ideas in a new way that brings benefits to the organization's operations. In the circumstances of rapid change. Creative developed employees, often beneficial for empowering methods to improve, new operational processes, organizations survive, and their performance has a competitive advantage. Interestingly, access to efficient operations (Dvir, Eden, Avolio, and Shamir, 2002), skills, knowledge, and organization abilities come from employees' potential (O'Cass and Sok, 2012).

Therefore, to encourage creative employees with new ideas causing the benefits to the organization. The search for novelty and exchange of learning to teamwork together causing innovative new products and services. Employee development to be creative and flexible to adapt to change, so employees should be encouraged to be creative. Giving employees independence will have to use the maximum skills to make the organization more profitable (Jituea and Jadesadalug, 2019; Siddiqi and Qureshi, 2016; Zhou and George, 2001). Supporting employees' creativity is a good incentive, either economically or living together in society, including creating positive attitudes towards behavior formation - the process of creating new things that create innovation ability of the organization cause a sustainable competitive advantage.

Creativity is the beginning of innovation with new ideas that can be used in operations, and employee creativity benefits the effectiveness and corporate innovation survival (Lee, Kim, Lee, and Moon, 2019). Employee development to create added value to the organization is essential to the organization's efficiency and effectiveness, including the creation of innovations (Sheehan, Garavan, and Carbery, 2014; Hassan, 2007). Thus, the new hypothesis is:

H2: Employee creativity development positively affects (a) organizational innovation capabilities and (b) outstanding performance.

\subsection{Organizational Innovation Capabilities}

Organizational innovation means a change in thinking. The process of operating an organization from something new or a new method cause to create the added value utilization that that occurs from creativity in finding new things (Crossan and Apaydin, 2010; McKeown, 2008). Occurred innovation in an organization is 
essential to driver outstanding performance. There is a competitive advantage in higher economic growth rate, and the network was created, or there is technological advancement, and new products or services are offered before rivals (Damanpour and Schneider, 2006; Edison, Ali, and Torkar, 2013; Lee, Florida, and Gates, 2010; Yen, 2014). An organization with innovative capabilities will develop new things continuously; it can be considered a strategy implementation in responding to environmental changes (Slater, Hult, and Olson, 2010; Gloet and Samson, 2016).

Innovation capability is essential to performance in an organization which is a change in the management system in the organization to develop to obtain something new. The different initiative to innovate from the competition, whether it is a model, an operating process, or a product and service, be like an organization culture that is open to new ideas with the presentation of the creativity of operations in a new way (Ferraresi et al., 2012; Hult, Hurley, and Knight, 2004; Wutthirong, 2015; Nybakk, Crispell, Hansen, and Lunnan, 2009). Having different innovative initiatives leads to the organization's development. The development of new ideas, behaviors, processes, operations, or products and services will lead to the organization's goal achievement (Romyen, 2019). The organization will achieve its goals; it is imperative to develop innovative capabilities and create new and different products. Entrepreneurs should realize the importance of operating or strategies to lead the organization to achieve long-term goals (Songsom, 2017; Suwannapusit and Chayomchai, 2018). Bring up a new hypothesis as follows:

H3: Organizational innovation capabilities have a positive effect on outstanding performance.

\subsection{Outstanding Performance}

Outstanding performance refers to the successful operations resulting from the company's efficient operation and having personnel who are well equipped in knowledge, skills, abilities, experience, and work with the potential which can be applied to operations appropriately and success. The outstanding performance can be verified from the financial results, clients, internal processes, learning, and company's growth performance (Kaplan and Norton,1992; Lalitsasivimol, 2016).

\section{Research Methodology}

\subsection{Sample and Data Collection}

This research has collected information from employment and income of SMEs businesses in Thailand; the data collected by 400 companies was a sample of this study from August to October 2020; the information is derived from the Office of Small and Medium Enterprise Promotion website http://www.sme.go.th. This study's primary informants were the managing director or managing partner, and data collection used the questionnaire via a mail survey procedure. Received 
questionnaire with complete answers 219 company form total 400 questionnaires. The effective response rate was $54.75 \%$ that is more than $20 \%$ for a mail survey response (Aaker, Kumar, and Day, 2001). The response rate for this study is therefore accepted. Finally, the non-responsive bias test refers to the concept of Armstrong and Overton (1977) by using the information on 109 early respondents and 110 late respondents then make a comparison using the company's demographic data, including business type, the duration of the company's work, number of employees in company by using t-test statistics. The test results showed that the company's demographics of the two groups were not significantly different. This indicates that the study did not have respondent bias problems in the questionnaire.

\subsection{Variables}

All variables in the model of this research measured by multi-item scales on a fivepoint Likert scale. Human capital orientation, employee creativity development, organizational innovation capabilities, and outstanding performance are the primary variable in this research. In this study, human capital orientation is the independent variable. It is meant to focus on the use of intellectual capital, skill, ability, and experience to increase the operational potential to achieve success. The development of both learning and organizational focus on adaptation, self-awareness, and competitive environment analysis. The Nineteen-item scale measure is adapted from Armstrong (2007). Next, Employee creativity development is meant to promote new ideas that are different and effective in work. It also fosters a commitment to work and being proactive self-development that can be applied to work creatively. The Twenty-six-item scale measure is adapted from George and Zhou (2001), Kanter (1998), Boonvatcharapai (2015), Jituea and Jadesadalug (2019).

Also, organizational innovation capabilities indicate the organization's ability to change, now operate a new process that makes increased value to the company. An organization with innovative capabilities will continuously develop innovations in product, marketing, processes, and strategies. The Nineteen-item scale measure is adapted from Wang and Ahmed (2004), Ferraresi et al. (2012), Rahab (2012). Lastly, outstanding performance is defined as an outstandingly successful operation in finance, clients, internal processes, and learning development. The Twenty-item scale measure is adapted from Kaplan and Norton (1992) and Lalitsasivimol (2016).

\subsection{The Test of Research Tool}

The quality of this research tool was checked. First, it tests the validity and reliability by using reliable questionnaires for the reliability of analysis from the alpha coefficient. According to Nunnally and Bernstein's concept, tool reliability in Table 1 shows between $0.88-0.98$, which is more significant than 0.70 (1994). Next, analysis of conformity with question by analyzing the item-total correlation. The resulting value is $0.45-0.93$, in which the discriminant power must be at least 0.40 (Kline, 1993). Finally, determination of structural straightness using 
confirmatory factor analysis with factor Loading between $0.69-0.98$, which is greater than 0.4. It showed that the questionnaires had reliability and it was valid. This is consistent with the recommendations of Nunnally and Bernstein (1994).

Table 1. The factor loading, item-total correlation, and alpha coefficient of constructs

\begin{tabular}{|l|c|c|c|}
\hline Constructs & $\begin{array}{c}\text { Factor } \\
\text { Loadings }\end{array}$ & $\begin{array}{c}\text { Item-total } \\
\text { Correlation }\end{array}$ & $\begin{array}{c}\text { Alpha } \\
\text { coefficient }\end{array}$ \\
\hline Human capital orientation (HMC) & $0.84-0.95$ & $0.72-0.86$ & 0.88 \\
Employee creativity development (EMP) & $0.69-0.98$ & $0.45-0.89$ & 0.96 \\
Organizational innovation capabilities & $0.79-0.94$ & $0.69-0.88$ & 0.98 \\
(OIN) & $0.74-0.96$ & $0.55-0.93$ & 0.96 \\
Outstanding performance (OUP) & & \\
\hline
\end{tabular}

Source: Own creation.

\subsection{Statistical Technique}

In this study, data analysis of variables including standard deviation, mean, and correlation coefficient. The ideal statistic for hypothesis testing is the Structural Equation Model (SEM), and it proceeds to investigate the effects of human capital orientation on employee creativity development, organizational innovation capabilities, and outstanding performance.

\section{Discussion of Results}

The display of the verification result of the relationship between the independent variables is shown in Table 2. It found that the variables are related to each other, statistically significant at a confidence level of 0.01 , and there is a correlation coefficient between the variable pairs between $0.48-0.73$ which the correlation coefficient is lower than 0.8 be at an acceptable level which shows that there was no problem about the independent variables (Hair, Black, Babin, and Anderson, 2010).

Table 2. Mean, standard deviation, and correlation matrix

\begin{tabular}{|l|l|l|l|l|}
\hline Variables & HMC & EMP & OIN & OUP \\
\hline Mean & 3.93 & 4.17 & 4.01 & 4.18 \\
\hline S.D. & 0.62 & 0.67 & 0.60 & 0.59 \\
\hline HMC & & & & \\
\hline EMP & $0.73^{* * *}$ & & & \\
\hline OIN & $0.48^{* * *}$ & $0.53^{* * *}$ & & \\
\hline OUP & $0.59^{* * *}$ & $0.72^{* * *}$ & $0.65^{* * *}$ & \\
\hline
\end{tabular}

Note: $* * p<.05, * * * p<.01$

Source: Own creation.

The path coefficient in Table 3 showed the relationship between human capital orientation, employee creativity development, organizational innovation capabilities, and outstanding performance, as shown in summary in Figure 2. This study 
examined the consistency of the model. It was found that the model was consistent with the empirical data. Determined by the chi-square statistics $\left(\chi^{2}\right)$ of the test results is equal to 156.25 at degrees of freedom $(\mathrm{df})$ as $102, \chi^{2} / \mathrm{df}=1.53$, the Incremental Fit Index (IFI) with the value of 0.99, the Normal Fit Index (NFI) is 0.98, the Root Mean Square Error of Approximation (RMSEA) with the value of 0.04. The Comparative Fit Index (CFI) is 0.99 pointed out that the model was very harmonious, which is considered from the proportionality criteria $\chi^{2} / \mathrm{df}$ should be no more than 3.00 (Schumacker and Lomax, 2010). CFI is typically between 0 and 1 . If the value is more significant than 0.95 or more, it is considered very well (Kline, 2010), NFI is more significant than 0.90 considered in good condition (Byrne, 1998). Also, the IFI value should be greater than 0.90, considered favorable (Byrne, 1998), and RMSEA should be between 0.05-0.08, so it is considered very well and if the RMSEA value is less than 0.08 is considered good, shows that the model is consistent with the empirical data (Kline, 2010).

Table 3. The results of path coefficients

\begin{tabular}{|c|c|c|c|c|c|c|c|c|c|}
\hline $\begin{array}{l}\text { Dependent } \\
\text { variable }\end{array}$ & \multicolumn{3}{|c|}{ EMP } & \multicolumn{3}{c|}{ OIN } & \multicolumn{3}{c|}{ OUP } \\
\hline $\begin{array}{l}\text { Independent } \\
\text { variable }\end{array}$ & TE & DE & IE & TE & DE & IE & TE & DE & IE \\
\hline HMC & $0.90 * * *$ & $0.90 * * *$ & - & 0.70 & -0.02 & 0.72 & 0.68 & -0.04 & 0.72 \\
\hline EMP & - & - & - & $0.80 * * *$ & $0.80 * * *$ & - & 0.82 & 0.09 & 0.73 \\
\hline OIN & - & - & - & - & - & - & $0.92 * * *$ & 0.92 & - \\
\hline Statistics & \multicolumn{8}{|c|}{$\chi^{2}=156.25, d f=102$} \\
\end{tabular}

Note: $T E=$ Total Effect, IE = Indirect Effect, DE = Direct Effect (Standard Errors: SE), *** $p<0.01$

Source: Own creation.

Figure 2. A summary of the relationships between integrated performance and company's success.

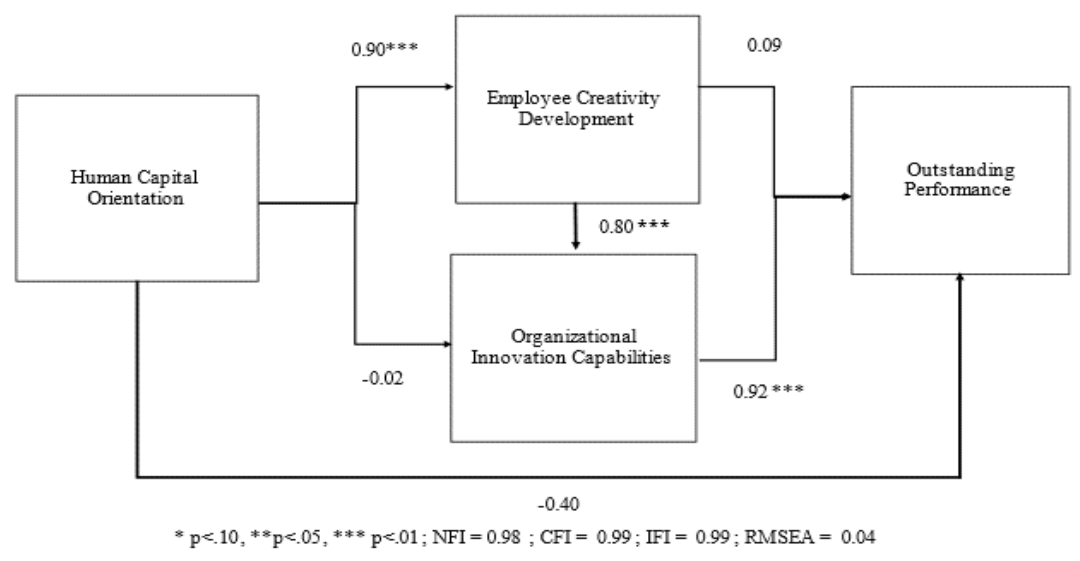

Source: Own creation. 
Moreover, Table 4 presented the effects of human capital orientation, employee creativity development, organizational innovation capability, and outstanding performance as a test. Firstly, human capital orientation positively affects employee creativity development $(b=0.90, p<0.01$, but human capital orientation has no significant relationship with organizational innovation capability $(b=-0.02)$ and outstanding performance $(b=-0.40)$. Human capital affects employee creativity development positively but, it still cannot affect the innovation capabilities and outstanding performance of the organization, due to the existed human capital in the organization if have not developed yet, it will not evoke the development of knowledge, skills, or creativity in doing new things or outstanding performance.

This is because human capital beings can be developed by accumulating knowledge, experience, and expertise. Focusing on creating human capital by fostering employees to gain new skills and the development of knowledge, capability, and value creation from expertise, these will be able to build their potential through learning. Therefore, employees have knowledge related to operations that essential for businesses that are adjusting or rehabilitating. Employee's creativity from prior knowledge foundations or reinvention is vital to the survival of an organization in an intensely competitive environment (Luepong, 2012; Khongrat, 2017). Thus, hypothesis $1 \mathrm{a}$ is supported, but hypotheses $1 \mathrm{~b}$ and $1 \mathrm{c}$ are not supported.

Secondly, employee creativity development positively affects organizational innovation capability $(b=0.80, p<0.01)$, but employee creativity development has no significant relationship with outstanding performance. Even though employees are trained to develop their knowledge and skills until having creativity, having only creativity does not directly impact outstanding performance because creativity creates the new and valuable thing that is gained by doing new things (Mumford, 2003; Stenberg and Stenberg, 2012). Employee's creativity development helps to use the knowledge, skills, and abilities gained from training.

This is a combination of knowledge and abilities of employees who work together to create new ideas for the added value that bring survival and increased productivity for the organization (Florida, 2002; Stenberg and Stenberg, 2012; Orchard, 2015; Urbano, Alvarez, and Turro, 2013). Organizational innovation capability is a successful implementation of the employee's creativity in the organization. Therefore, Hypothesis 2a is supported, but hypothesis $2 \mathrm{~b}$ is not supported.

Thirdly, organizational innovation capability positively affects to outstanding performance $(b=0.92, p<0.01)$. The company's innovative capabilities generate innovative initiatives that can create value for the unique novelty product. This shows the product differentiation ability with the competitiveness (Wang and Ahmed, 2004; Lin, Chen, and Chiu, 2010; Karnjanakunchorn, 2017). It can also enter new marketing channels, new customers easy to access the market, have more income, and reduce operating costs from developing new marketing models for increasing competitiveness (Wang and Ahmed, 2004; Yotyingyong, 2009). 
New process capabilities from existing resources in the organization also develop new production processes or methods, which is a creative ability (Wang and Ahmed, 2004; Suwannapusit and Chayomchai, 2018) as applying modern technology to enhance the operational capability of the organization. Moreover, strategic competence can be applied to operate in changing situations appropriately to increase value to the organization, affecting long-term competitive advantages (Nybakk et al., 2009; Ferraresi et al., 2012; Songsom, 2017). Therefore, Hypothesis 3 is supported.

Table 4. The summary of hypotheses testing

\begin{tabular}{|l|l|l|l|}
\hline Hypotheses & \multicolumn{1}{|c|}{ Relationships } & \multicolumn{1}{c|}{ Coefficients } & \multicolumn{1}{c|}{ Results } \\
\hline H1a & HMC $\rightarrow$ EMP & $0.90^{* * *}$ & Supported \\
\hline H1b & HMC $\rightarrow$ OIN & -0.02 & Not Supported \\
\hline H1c & HMC $\rightarrow$ OUP & -0.40 & Not Supported \\
\hline H2a & EMP $\rightarrow$ OIN & $0.80^{* * *}$ & Supported \\
\hline H2b & EMP $\rightarrow$ OUP & 0.09 & Not Supported \\
\hline H3 & ION $\rightarrow$ OUP & $0.92^{* * *}$ & Supported \\
\hline
\end{tabular}

Note: $* p<.10, * * p<.05, * * * p<.01$

Source: Own creation.

In summary, human capital is the most critical resource to the organization. They provide support for the development of human potential by enhancing knowledge, training, expertise, continuous learning, and the necessary experience for working regularly. Human capital can create value for the organization, bringing about changes in operating behavior with a new idea through self-development, and people can collaborate effectively (Chueabangkaew, 2008). Therefore, executives should realize that investment in human resources within the organization is essential. People are assets without depreciation and intangible but can be developed to enhance the knowledge and capability by integrating many fields of knowledge and skills. People are the human capital that can always increase value to the organization (Wang et al., 2010; Hareebin, 2020).

\section{Contributions and Suggestions for Future Research}

\subsection{Theoretical Contribution}

This research integrates three concepts of the resource base theory, contingency theory, and dynamic capabilities that SMEs use to create values and competence in situations facing threats from the external environment. Those severely impact their operations, conduct a test of the human capital effect on employee creativity development, organizational innovation capabilities, and an organization's outstanding performance. Empirical confirmation that the human capital orientation positively affects employee creativity development both knowledge, skills, and abilities. Employees could apply creative thinking for doing new things and operations that resulted in creating innovation ability. The creative ability in an 
organization is so important that it results in a more competitive and successful company.

Therefore, SMEs companies require to rehabilitate their businesses should realize the importance of human capital development. Employees should be trained, knowledgeable, and skilled to operate constructively. This will be the source of long-term advantage operations over competitors. Future research should study the antecedents of human capital orientation and relationship administrator to enable this study to be used in organizational management for better performance. The data should be collected with other industrial demographics to compare the differences as well as having developmental guidelines for the organization in other fields to be competitive or use other statistical techniques to test relationship to prove the effect to be universal acceptance.

\subsection{Managerial Contribution}

An emphasis on the existing development of creativity of human capital in the organization. This results in the ability to create innovation that leads the organization to outstanding performance. This is because the employees have successfully applied their knowledge and skills to perform their work in an external environment where companies are affected by the coronavirus epidemic. Therefore, SME companies that are accelerating recovery can apply information to benefit the company's human capital development. The company encourages employees to think joint initiative and create something new that is ready to cope with the organization's changes to relate with innovation and new information technology to lead the organization to survive and gain a competitive advantage. Human capital is a factor that corporate executives need to realize and attention to the development and retention of employees with creative thinking, skills, knowledge, and abilities to develop performance towards the organization's sustainability.

\section{Conclusion}

Human capital orientation can bring success to the organization. If the organization realizes the importance as an asset to the organization and supports the development to create value, that is difficult to copy, and it can help the company perform above the competition. This research tries to test the effect of human capital orientation, employee creativity development, organizational innovation capabilities, and outstanding performance of Thailand's SMEs companies with 219 SMEs businesses were a sample of the research. The statistics used to test the relationship in this research were the Structural Equation Model (SEM). This research found human capital orientation positively affects employee creativity development but does not directly affect organizational innovation capabilities and outstanding performance. Next, employee creativity development positively affects organizational innovation capabilities. 
Furthermore, organizational innovation capabilities positively affect outstanding performance. Hence, to bring more benefits from the use of human capital orientation, it is necessary to focus on human capital in the organization to plan the allocation and development of the existing workforce to create value for the organization. Organizations can be adapted and prepared to cope with the volatility of the faced environment. Future research should study antecedent information that affects human capital development to suit the organization context to review and expand the current study result. Collection data from other industry populations to compare the differences and use it as a guideline for developing the organization to be competitive and using other statistical techniques to test the results of the study to achieve international acceptance.

\section{References:}

Aaker, D.A., Kumar, V., Day, G.S. 2001. Marketing research. New York, NY: John Wiley and Sons.

Abdul-Mohsin, A.M., Halim, H.A., Ahmad, N.H. 2020. Determinants of innovative performance: The Case of an emerging country SMEs. International Journal of Economics and Business Administration, 8(4), 3-19.

Alsafadi, Y., Altahat, S. 2021. Human resource management practices and employee performance: The role of job satisfaction. Journal of Asia Finance, Economics and Business, 8(1), 519-529. http://doi:10.13106/jafeb.2021.vol8.no1.519.

Armstrong, J.S., Overton, T.S. 1977. Estimating non-response bias in mail surveys. Journal of Marketing Research, 14(3), 396-402.

Armstrong, M. 2007. Strategic human resource management. $4^{\text {th }}$ ed. London: Kogan page limited.

Barney, J. 1991. Firm resources and sustained competitive advantage. Journal of Management, 17(1), 99-120.

Baron, A., Armstrong, M. 2007. Human Capital Management: Achieving added value Through people. London: Kogan Page.

Boonvatcharapai, T. 2015. Organizational Creativity for Service Innovation and Business Performance: An Empirical Phenomenon of Thai Boutique Hotel. Doctoral Dissertation in Management. Silpakorn University.

Byrne, B.M. 1998. Structural Equation Modeling with LISREL, PRELIS, and SIMPLIS: Concepts, Applications, and Programming. Mahwah, NJ: Erlbaum.

Chueabangkaew, P. 2008. Human resource management. Bangkok: Bangkok University Press.

Crossan, M.M., Apaydin, M. 2010. A multi-dimensional framework of organizational innovation: A systematic review of the literature. Journal of Management Studies, 47(6), 1154-1191.

Damanpour, F., Schneider, M. 2006. Phases of the adoption of innovation in organizations: Effects of environment, organization, and top managers. British Journal of Management, 17(3), 215-236. http://doi: 10.1111/j.1467-8551.2006.00498.x.

Dechawatanapaisal, D. 2017. Examining the relationships between HR practices, organizational job embeddedness, job satisfaction, and quit intention Evidence from Thai accountants. Asia Pacific Journal of Business Administration, 10(2/3), 130-148. 
Dvir, T., Eden, D., Avolio, B., Shamir, B. 2002. Impact of transformational leadership on follower development and performance: A field experiment. Academy of Management Journal, 45, 735-744.

Edison, H., Ali, N., Torkar, R. 2013. Toward innovation measurement in the software industry. The Journal of Systems Software, 86(5), 1390-1407. http://doi: 10.1016/j.jss.2013.01.013.

Ehrenberg, R.G., Smith, R.S. 2003. Modern labor economics. Boston: Addison Wesley.

Ferraresi, A.A., Quandt, C.O., Santos, S.A., Frega, J.R. 2012. Knowledge management and strategicorientation: leveraging innovativeness and performance. Journal of Knowledge Management, 16(5), 688-701. http://doi: $10.1108 / 13673271211262754$.

Florida, R. 2002. The raise of creative class. New York: Basic Books.

George, J. M., Zhou, J. 2001. When openness to experience and conscientiousness are related to creative behavior: An interactional approach. Journal of Applied Psychology, 86(3), 513-524. https://doi.org/10.1037/0021-9010.86.3.513.

Gloet, M., Samsom, D. 2016. Knowledge management and systematic innovation capability. International Journal of Knowledge Management, 12(2), 54-72. https://doi.org/10.4018/IJKM.2016040104.

Hair, J.F., Black, W.C., Babin, B.J., Anderson, R.E. 2010. Multivariate data analysis: a global perspective (7th ed.). Upper Saddle River, NJ: Person Prentice Hall.

Hareebin, Y. 2020. Human capital development in the strategy of innovation entrepreneurs. Journal of Economics and Management Strategy, 7(1), 159-172. https://kuojs.lib.ku.ac.th/index.php/jems/article/view/2612.

Hariyono, A., Tjahjadi, B. 2021. The role of intellectual capital in the development of financial technology in the new normal period in Indonesia. Journal of Asia Finance, Economics and Business, 8(1), 217-224. http://doi:10.13106/jafeb.2021.vol8.no1.217.

Hassan, A. 2007. Human resource development and organizational values. Journal of European Industrial Training, 31(6), 435-448. http://doi: 10.1108/03090590710772631.

Hatch, N.W., Dyer, J.H. 2004. Human capital and learning as a source of sustainable competitive advantage. Strategic Management Journal, 25(12), 1155-1178. https://doi.org/10.1002/smj.421.

Hult, G.T.M., Hurley, R.F., Knight, G.A. 2004. Innovativeness: Its antecedents and impact on business performance. Industrial Marketing Management, 33(5), 429-438. http://dx.doi.org/10.1016/j.indmarman.2003.08.015.

Jansawang, K., Prombutara, S. 2019. Human capital with change: A paradigm shift of human resource management. Journal of Management Sciences, 6(2), 209-222.

Jituea, N., Jadesadalug, V. 2019. Promoting the creative work behavior to innovation effectiveness and organizational performance. MUT Journal of Business Administration, 16(1), 200-229.

Kaplan, R.S., Norton, D.P. 1992. The balanced scorecard - measures that drive performance. Harvard business review.

Karnjanakunchorn, J. 2017. Marketing innovations that affect the decision to purchase computer equipment of group Intel and AMD, consumers late teens to work in Bangkok. Master of Business Administration. Graduate school, Bangkok University. 
Kanter, R.M. 1998. When a thousand flowers bloom: Structural, collective, and social Conditions for innovation in organizations. In Research in Organizational Behavior, 10, 169-211. Staw, B.M., Cummings, L.L. editors.

Kelliher, F., Reinl, L. 2009. A resource-based view of micro-firm management practice. Journal of Small Business and Enterprise Development, 16(3), 521-532. http://doi: 10.1108/14626000910977206.

Khongrat, T. 2017. Factors of creativity and idea management and employee competency that contribute to innovation organization case study tire manufacturer in Thailand. A thesis submitted in partial fulfillment of the requirements for the degree of Master of Science Technology Management College of innovation Thammasat University.

Kline, P. 1993. The handbook of psychological testing. London: Routledge.

Kline, R.B. 2010. Principles and Practice of Structural Equation Modeling (3rd.). New York: Guilford Press.

Lalitsasivimol, W. 2016. The structural equation model human capital development affecting the competitive advantage for performance success of private businesses in Songkhla Province. MUT Journal of Business Administration, 13(2), 79-99.

Lee, J., Kim, S., Lee, J., Moon, S. 2019. Enhancing employee creativity for a sustainable competitive advantage through perceived human resource management practices and trust in management. Sustainability, 11(8), 2035. https://doi.org/10.3390/su11082305.

Lee, S.Y., Florida, R., Gates, G. 2010. Innovation, human capital, and creativity. International Review of Public Administration, 14(3), 13-24. https://doi.org/10.1080/12294659.2010.10805158.

Lin, R.J., Chen, R., Shun Chiu, K.K. 2010. Customer relationship management and innovation capability: An empirical study. Industrial Management \& Data Systems, 110(1), 111-133. http://doi: 10.1108/02635571011008434.

Luepong, P. 2012. The competency development of human resource. Executive Journal, 32(4), 103-108.

Mahsud, R., Yukl, G., Prussia, G.E. 2011. Human capital, efficiency, and innovative adaptation as strategic determinants of firm performance. Journal of Leadership \& Organizational Studies, 18(2), 229-246. https://doi.org/10.1177/1548051811400750.

McCulloch, A. 2020. Staff face temporary redundancies and reduced hours. Personnel Today. Retrieved from: https://www.personneltoday.com/hr/businesses-facereducing-employees-hours-and-temporary-redundancies/.

McKeown, M. 2008. The truth about innovation. London: Prentice Hall.

Milumaieng, K. 2016. Recruitment and selection of human resources in modern public organizations. Journal of Humanities and Social Sciences Suratthani Rajabhat University, 8(1), 131-152.

Mumford, M.D. 2003. Where have we been, where are we going? Taking stock in creativity research. Creativity Research Journal, 15, 107-120. http://doi: 10.1080/10400419.2003.9651403.

Nguyen, D.T., Ha, V.D., Dang, T.T.N. 2020. The impact of human resource management activities on the compatibility and work results. Journal of Asian Finance, Economics and Business, 7(9), 621-629. https://doi.org/10.13106/jafeb.2020. vol7.no9.621.

Nunnally, J.C., Bernstein, I.H. 1994. Psychometric theory. New York, NY: McGraw-Hill. 
Nybakk, E., Crespell, P., Hansen, E., Lunnan, A. 2009. Antecedents to forest owner innovativeness: An investigation of the Non-timber forest products and services sector. Forest Ecology and Management, 257(2), 608-618. http://doi: 10.1016/j.foreco.2008.09.040.

O'Cass, A., Sok, P. 2012. Examining the role of within functional area resource-capability complementarity in achieving customer and product-based performance outcomes. Journal of Strategic Marketing, 20(4), 345-363. https://doi.org/10.1080/0965254X.2011.643918.

Office of Small and Medium Enterprises Promotion. 2020. Executive summary report of the state of Small and Medium Enterprises, online, from: https://www.sme.go.th/upload/mod_download/download-20200824164414.pdf.

Onkelinx, J., Manalova, T.S., Edelman, L.F. 2016. The human factor: Investments in employee human capital, productivity, and SME Internationalization. Journal of International Management, 22(4), 351-364. https://doi.org/10.1016/j.intman.2016.05.002.

Orchard, S. 2015. Entrepreneurship and the human capital of organization innovation: the intrapreneur. In: Sindakis, S., Water, C. The Entrepreneur rise in Southeast Asia: the quadruple helix influence on technological innovation, 111-138. New York: Palgrave Macmillan. https://link.springer.com/chapter/10.1057/9781137373809_6.

Pinkesorn, K., Kittisaknawin, C., Kongklai, C. 2017. Human capital: Corporate human capital scorecard. Journal of graduate studies Valaya Alongkorn Rajabhat University, 11(2), 193-202.

Ployhart, R.E., Van Iddekinge, C.H., Mackenzie Jr., W.I. 2011. Acquiring and developing human capital in service contexts: The interconnectedness of human capital resources. Academy of Management Journal, 54(2), 353-368. https://doi.org/10.5465/amj.2011.60263097.

Rahab, R. 2012. Innovativeness model of small and medium enterprises based on market orientation and learning orientation: Testing moderating effect of business operation mode. Procedia-Social and Behavioral Sciences, 4, 97-109. https://doi.org/10.1016/S2212-5671(12)00325-5.

Robbins, S.P., Coulter, M. 2016. Management $11^{\text {th }}$ ed., (Global Edition). New Jersey: Prentice Hall International.

Romyen, S. 2019. Influence of innovativeness and marketing capability toward firm performance of SMEs in Songkhla Province. A thesis submitted in partial fulfillment of the requirements for the Degree of Master of Business Administration Prince of Songkla University.

Schumacker, R.E., Lomax, R.G. 2010. A beginner's guide to structural equation modeling (3rd ed.). New York: Taylor and Francis Group.

Sheehan, M., Garavan, T.N., Carbery, R. 2014. Innovation and human resource development (HRD). European Journal of Training and Development 38(1/2), 2-14. https://doi.org/10.1108/EJTD-11-2013-0128.

Siddiqi, H., Qureshi, M. 2016. The impact of employees' creativity on performance of the firm. Research issues in social sciences, 1, 1-12.

Sijabat, E.A.S., Nimran, U., Utami, H.N., Prasetya, A. 2021. The effects of dynamic capabilities, entrepreneurial creativity, and ambidextrous innovation in firm competitiveness. Journal of Asia Finance, Economics and Business, 8(1), 711 721. http://doi:10.13106/jafeb.2021.vol8.no1.711. 
Slater, S.F., Hult, G.T.M., Olson, E.M. 2010. Factors influencing the relative importance of marketing strategy creativity and marketing strategy implementation effectiveness. Industrial Marketing Management, 39(4), 551-559. http://doi:10.1016/j.indmarman.2008.03.007.

Songsom, A. 2017. Innovativeness: Literature review and proposed conceptual model for examining the antecedents and consequences. University of Thai Chamber of Commerce Journal, Humanities and Social Sciences, 37(4), 182-194.

Stemberg, R.J., Stenberg, K. 2012. Cognitive Psychology (6th ed). Belmonth: Cengage Leaning.

Subramanian, A.M. 2012. A longitudinal study of the influence of intellectual human capital on firm exploratory innovation. IEEE Transactions on Engineering Management, 59(4), 540-550. http://doi: 10.1109/TEM.2011.2179648.

Suwannapusit, U., Chayomchai, A. 2018. Innovations and their effects on One Tambon One Product (OTOP) enterprises' performance in Thailand. University of the Thai Chamber of Commerce Journal, Humanities and Social Sciences, 38(1), 18-35.

Thammawimutti, A., Chuntuk, T. 2017. Innovative and creative human capital of community enterprise entrepreneurs. Veridian E Journal, Silpakorn University, 10(1), 15721589.

Thomas, D., Campbell, P., Hancock, A. 2020. Companies from ford to Unilever send staff to work from home. The Financial Times. https://www.ft.com/content/1d54d08a6555-11ea-b3f3-fe4680ea68b5.

Urbano, D., Alvarez, C., Turro, A. 2013. Organizational resources and intrapreneurial activities: An international study. Management Decision, 51(4), 854-870. http://doi: 10.1108/00251741311326617.

Wang, C.L., Ahmed, P.K. 2004. The development and validation of the organizational innovativeness construct using confirmatory factor analysis. European Journal of Innovation Management, 7(4), 303-313. http://doi: 10.1108/14601060410565056.

Wang, C.L., Ahmed, P.K. 2007. Dynamic capabilities: A review and research agenda. International Journal of Management Reviews, 9(1), 31-51. https://doi.org/10.1111/j.1468-2370.2007.00201.x.

Wang, Y.L., Wang, Y.D., Horng, R.Y. 2010. Learning and innovation in small and medium enterprises. Industrial Management and Data Systems, 110(2), 175-192. http://doi 10.1108/02635571011020296.

Wei, T.T., Wong, L. 2020. Firms urged to stagger work hours, let staff work from home. The Straits Times. https://www.straitstimes.com/singapore/firms-urged-to-staggerwork-hours-let-staff-work-from-home.

Wolor, C.W., Solikhah, S.D., Martono, S. 2020. How to maintain employee motivation amid the Covid-19 virus pandemic. International Journal of Economics and Business Administration, 8(4), 78-86.

Wutthirong, P. 2015. Innovation management: Resource, learning organization and innovation. Bangkok, Thailand: Chulapress.

Yen, Y.F. 2014. The impact of bank's human capital on organizational performance: How innovation influences performance. Innovation: Management, Policy \& Practice, 15(1), 112-128. https://doi.org/10.5172/impp.2013.15.1.112.

Yodyingyong, K. 2009. Innovation organization: Concept \& process. Bangkok: Chulalongkorn University Printing House.

Zhou, J., George, J.M. 2001. When Job Dissatisfaction Leads to Creativity: Encouraging the Expression Voice. Academy of Management Journal, 44(4), 682-696. 